\title{
Customer participation in new product development: an Industry 4.0 perspective
}

\author{
Hafiz Muhammad Naeem and Eleonora Di Maria \\ Department of Economics and Management, University of Padua, Padua, Italy
}

\begin{abstract}
Purpose - The use of modern technologies of the fourth industrial revolution, commonly known as "Industry 4.0" (I4.0), is believed to have considerable potential for product customisation. In this context, this paper aims to explore whether or not using these technologies impacts customer participation $(\mathrm{CP})$ in a firm's new product development (NPD) process.

Design/methodology/approach - To empirically test the proposed relationships, the authors collected the North Italian manufacturing firms' data and applied regression analysis.

Findings - Empirical results indicate that, on the one hand, the technologies have their specific and individual impacts, and on the other hand, the firms which use more I4.0 technologies allow more customer participation in their product design and production process. This positive impact is more robust in product design than in the production process.

Practical implications - Managers aiming to benefit from $\mathrm{CP}$ should broaden the scope of adopting I4.0 technologies and consider different roles concerning the design and production phases of the new product development process. Recognising the importance and allowing CP in NPD will enable firms to meet the customised demands.

Originality/value - To the best of the authors' knowledge, the proposed relationships of this study have been extensively debated theoretically in the I4.0 context but never empirically tested before. It is one of the few studies which discusses the strategic adoption and the combined use of I4.0 technologies to create more opportunities for product customisation.
\end{abstract}

Keywords Industry 4.0, Customer participation, New product development, Product design, Production process Paper type Research paper

\section{Introduction}

Manifested in the intensive use of modern technologies, "Industry 4.0" (I4.0) is hailed as a new manufacturing paradigm. Since its induction by the Germans at "Hannover Messe 2011", I4.0, also known as the fourth industrial revolution, is one of the most trending subjects among academics and practitioners alike (Liao et al., 2017; Chiarello et al., 2018). During the time of I4.0, the market has become more competitive than ever and posits several challenges requiring a swift response from companies to improve and meet the demand for customised products (Kolberg et al., 2017; Buer et al., 2018).

Courtesy of the rise of information and communication technologies (ICT), transparency between customers and firms has increased (Nambisan, 2002), and a higher number of firms are assuring customer participation (CP) in their new product development (NPD) process

(C) Hafiz Muhammad Naeem and Eleonora Di Maria. Published by Emerald Publishing Limited. This article is published under the Creative Commons Attribution (CC BY 4.0) licence. Anyone may reproduce, distribute, translate and create derivative works of this article (for both commercial and noncommercial purposes), subject to full attribution to the original publication and authors. The full terms of this licence may be seen at http://creativecommons.org/licences/by/4.0/legalcode

The research presented in this article has been financially supported by the project "Manufacturing activities and value creation: redesigning firm's competitiveness through digital manufacturing in a circular economy framework" - grant no. BIRD161248/16 (University of Padova, Department of Economics and Management).

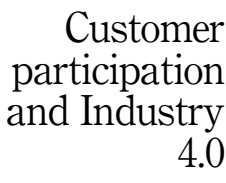

Received 17 January 2021 Revised 28 April 2021 Accepted 26 May 2021 
EJIM

25,6

638

(Fang, 2008). CP is defined as the magnitude of the customer's engagement in a company's NPD process (Fang, 2008). At first, firms started listening to the "voice of the customer" to identify their unmet needs and solutions (Griffin and Hauser, 1993). However, CP has evolved to the point that now firms accept customer inputs during all phases of NPD (Morgan et al., 2018). Concepts like lead users, user toolkits and virtual customer communities have appeared in the literature (von Hippel, 1986, 2001; Nambisan, 2002) to highlight this shift in approach towards NPD. Recent work gives formal recognition to CP in NPD (Chang and Taylor, 2016) by acknowledging various participation roles a customer can take on in NPD, that is, the customer as an information source, a co-developer and an innovator (Cui and $\mathrm{Wu}, 2016,2017$ ).

Existing studies have affirmed that $\mathrm{CP}$ helps in bringing not only product innovation (Fang, 2008) but also the economic (Hibbert et al., 2012) and relational values (Troye and Supphellen, 2012) and reduces uncertainty (Watson et al., 2018). Nevertheless, the NPD process is diffused with conflict (Xie et al., 1998; Song et al., 2006) and adverse outcomes like inefficient NPD processes and inferior NPD performance due to increased complexity of knowledge management from different sources for NPD (Chang and Taylor, 2016). However, scholars consider the investment in modern technologies a significant internal factor to cater to consumers' customised demand (Kotha, 1996). Therefore, it is essential to reconsider the perspective of CP in NPD in the I4.0 scenario.

The technologies of I4.0 are interactive by nature, and products manufactured through these technologies have a higher value because the customers can participate in the value creation process with these technologies (Rayna and Striukova, 2016). Given that the I4.0 technologies can fulfil the promise of individually customised production at the cost of mass production (Wang et al., 2016), companies are getting closer to these technologies for product development purposes (Rauch et al., 2016). For example, technologies like Internet of Things (IoT), robotics, big data analytics (Gress and Kalafsky, 2015; Sestino et al., 2020) and direct digital manufacturing, an umbrella term that includes technologies like additive manufacturing (AM) and 3D printing (Holmström et al., 2016), help in manufacturing individually customised products.

The prior literature mainly focuses on technical aspects of technologies and infrequently discusses the strategic view of their adoption. Ramaswamy and Ozcan (2018a, b) state that "merely looking at the phenomena of co-creation through the lens of activities that tended to dominate the literature, missed the weaker signals of interactional creation, which was being enhanced by a new age of interconnections catalysed by technology and digitalisation” (p. 197). Schwab (2016), the founder and executive chairman of the World Economic Forum, associates the "technology-enabled platform" with I4.0. Researchers believe that product development, that is, product design and engineering process (Chang and Taylor, 2016), could be a potential field to benefit from these technologies (Rauch et al., 2017). Therefore, a strategic perspective seems crucial to understand how a firm can incorporate customers' input successfully (Cui and $\mathrm{Wu}, 2018$ ) in the I4.0 context. I4.0 is not solely about technologies per se but the strategic adoption and combined use of technologies to better explore and create opportunities, especially in the NPD domain. This connectivity between technologies is not extensively discussed before 2011. It is only recently enabled when the technologies have reached a mature state of the application and are materialised under the concept of I4.0 (Santos et al., 2017). Additionally, even if the number of publications in the I4.0 domain is on the rise, the extant literature has sparse empirical evidence validating the firm's perspective towards I4.0 (Lin et al., 2018). Moreover, I4.0 studies dominate subject areas like computer science and engineering, whereas the number of articles in the business and management field is relatively lower (Liao et al., 2017).

We contend that the emerging technological scenario of I4.0 provides an interactive platform that helps produce customised products. On the one hand, I4.0 technologies are interactional and have their specific characteristics and functions. On the other hand, the combined use of these technologies creates more customer engagement and product customisation chances. Therefore, we argue that the companies that adopt a higher number 
of I4.0 technologies allow more CP in NPD due to the additional opportunities of interaction created by the combined use of technologies. We empirically analyse this proposition by using the data of Northern Italian firms already using I4.0 technologies. All in all, this study aims at understanding whether or not firms using more I4.0 technologies allow more $\mathrm{CP}$ in NPD, that is, product design and product development.

The remainder of the paper is structured as follows: Section 2 consists of a brief literature review on I4.0 and CP in NPD and hypotheses development thereof. Section 3 discusses the research design and data analysis. The empirical model and the results are discussed in Section 4. Section 5 discourses the results and their managerial and practical implications. Finally, we conclude the paper in Section 6 and point out the limitations and future research directions.

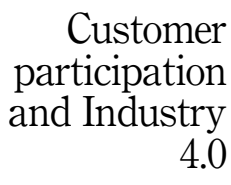

639

\section{Theoretical background and hypotheses development}

\subsection{The concept of Industry 4.0}

Instead of a single breakthrough invention, I4.0 consists of numerous tech components evolving into new enabling technologies through mutual combination and convergence (Drath and Horch, 2014; OECD, 2017). For example, Chiarello et al. (2018) identified 1,211 single technological components referring to 30 disciplinary fields. This increased complexity makes it challenging for manufacturing firms to understand the concept of I4.0 (Ghobakhloo, 2018). On the one hand, particularly in the initial phase of technological transition towards I4.0, researchers and practitioners have shown faith in I4.0 (Liu and $\mathrm{Xu}, 2016$ ) regarding arising possibilities and opportunities. On the other hand, there is a higher degree of uncertainty about the resource commitments in new technologies and their impacts on firms' performance. This discrepancy seems plausible due to the variety of scientific disciplines like engineering, computer science, business management and economics involved in the research and implementation of I4.0. This diversity of fields also impedes the development of uniform definition. Germany's digital association, BITKOM, has highlighted almost 100 definitions of I4.0 (Bidet-Mayer and Ciet, 2016). It can be defined as a merger of technologies ranging from various digital technologies (Koh et al., 2019) or a new production paradigm focused on the outcome of transformation processes (Weking et al., 2020). According to Gilchrist (2016), "Industry 4.0 is essentially a revised approach to manufacturing that makes use of the latest technological inventions and innovations, particularly in merging operational and information and communication technology." Table 1 provides existing definitions of I4.0 and highlights the diverse perspectives and points of impact explored by different scholars. The most cited definitions are the ones given by Hermann $e t a l$. (2016), Lasi et al. (2014), and Drath and Horch (2014), respectively. A shared feature of all these definitions is the "techno-centric" perspective, meaning that the peculiarity of this industrial revolution is the technological advancements (Cimini et al., 2020).

Although I4.0 is a sum of numerous technologies and is associated with technological megatrends like AM, IoT, digitalisation, and increased automation in manufacturing processes (Liao et al., 2017), modern digital technologies like the IoT, big data, 3D printing, augmented and virtual reality, and robotics constitute the backbone of the fourth industrial revolution (Bressanelli et al., 2018). Table 2 provides an overview of the most prominent I4.0 technologies. The concept of I4.0 is originally aimed at highlighting the impact of technologies in the manufacturing realm (Kagermann et al., 2013), and the most common expectations from I4.0 are related to higher flexibility and productivity (Culot et al., 2020). Even though the I4.0 tools may require higher expertise and significant investments (Rüßmann et al., 2015), it appears to be more flexible due to decentralised decision-making and information (Moeuf et al., 2017). Consequently, I4.0 has the aptitude of transforming the nature of products and services offered by the firms (Porter and Heppelmann, 2014). So, companies are adopting these technologies to face challenges like customised products and a batch size of one (Bauernhansl et al., 2014). The motivation behind I4.0 - the sum of various 


\section{EJIM 25,6}

640

\begin{tabular}{l} 
Author \\
\hline $\begin{array}{l}\text { Kolberg et al. } \\
\text { (2017) }\end{array}$ \\
Hermann et al. \\
(2016)
\end{tabular}

Ivanov et al. (2016)

Kang et al. (2016)

Schmidt et al. (2015)

Maynard (2015)

Drath and Horch (2014)

Lasi et al. (2014)

Table 1.

Kagermann et al. (2013)

Existing definitions and the perspective of I4.0 (temporal order)
Definition

"Industry 4.0 is the vision of smart components and machines which are integrated into a common digital network based on the well-proven Internet standards" "The convergence of industrial production and information and communication technologies, called Industrie 4.0 [...]"; "In this publication, the authors name three key components of Industrie 4.0: the IoT, CyberPhysical Systems (CPS), and Smart Factories" "Industry 4.0 represents a smart manufacturing networking concept where machines and products interact with each other without human control" "Industry 4.0 or Smart Manufacturing is the fourth industrial revolution. It is a new paradigm and convergence of cutting-edge ICT and manufacturing technologies. It provides ground for making effective and optimized decisions through swifter and more accurate decision-making processes"

"Industry 4.0 shall be defined as the embedding of smart products into digital and physical processes. Digital and physical processes interact with each other and across geographical and organizational borders"

“fourth industrial revolution'.... is an approach that focuses on combining technologies such as additive manufacturing, automation, digital services and the internet of Things, and it is part of a growing movement towards exploiting the convergence between emerging technologies"

"Industrie 4.0 refers to the fourth industrial revolution and is often understood as the application of the generic concept of cyberphysical systems (CPSs) to industrial production systems (cyber-physical production systems)" "The term Industry 4.0 collectively refers to a wide range of current concepts, whose clear classification concerning a discipline as well as their precise distinction is not possible in individual cases. [...] The concepts are: smart factory [...], cyber-physical systems [...], selforganization [...], new systems in distribution and procurement [...], new systems in the development of products and services [...], adaptation to human needs and corporate social responsibility [...]"

"Industrie 4.0 will involve the technical integration of CPS into manufacturing and logistics and the use of the internet of Things and Services in industrial processes. This will have implications for value creation, business models, downstream services and work organisation"
Focal point

Digitised production

Intersection of production and technology

Supply chain

Efficiency of decisionmaking process

Customisation, production time

Social, environmental and economic aspects

Connectivity of physical and virtual world

Sum of various concepts

Value creation, business model

technologies to strategically inspire the innovation of the current manufacturing industry by blending information, technology and humans - is smart manufacturing (Kang et al., 2016). It has helped firms to be more consumer-centric, and $\mathrm{CP}$ has become more accustomed to the possibility of all creative work done by customers (Bogers et al., 2016). These technologies provide high flexibility, make the production process transparent and enhance capabilities to produce individualised products with increased productivity, high quality and low costs 


\begin{tabular}{|c|c|c|c|}
\hline Authors & Technology & Impact/function & $r$ \\
\hline Berman (2012) & $3 \mathrm{D}$ printing & $\begin{array}{l}\text { Production of customised goods and company operations } \\
\text { at no or little unsold inventory }\end{array}$ & and Industr \\
\hline $\begin{array}{l}\text { Chan et al. (2018), Esmaeilian et al. } \\
\text { (2016), Huang et al. (2013) }\end{array}$ & $\mathrm{AM}$ & $\begin{array}{l}\text { Computer-aided design is used as an input to develop } \\
\text { parts by putting layers of molten material on each other } \\
\text { based on the angles and symmetries of CAD model }\end{array}$ & \\
\hline \multirow[t]{2}{*}{ Yew et al. (2016), Doshi et al. (2017) } & \multirow[t]{2}{*}{$\mathrm{AR}$} & $\begin{array}{l}\text { Helps to visualize the computer graphics of the real } \\
\text { environment }\end{array}$ & 641 \\
\hline & & $\begin{array}{l}\text { Real-time operation planning and control, defect } \\
\text { diagnoses and recoveries and training concerning } \\
\text { products and processes }\end{array}$ & \\
\hline IFR (2017), Esmaeilian et al. (2016) & Robotics & $16 \%$ increase in the sale of robots & \\
\hline \multirow{2}{*}{$\begin{array}{l}\text { Jeschke et al. (2017), Al-Fuqaha } \\
\text { et al. (2015) }\end{array}$} & \multirow[t]{2}{*}{ IoT } & $\begin{array}{l}\text { Lower defect rates, reliability, and high quality } \\
\text { Communication between physical object, information } \\
\text { sharing }\end{array}$ & \\
\hline & & $\begin{array}{l}\text { Digital representation of manufacturing infrastructure, } \\
\text { processes and products }\end{array}$ & \\
\hline $\begin{array}{l}\text { Lavalle et al. (2011), Babiceanu } \\
\text { and Seker (2016) }\end{array}$ & Big data & $\begin{array}{l}\text { Extract value from a massive volume of information } \\
\text { Positive influence on performance, maintenance and } \\
\text { product customisation }\end{array}$ & $\begin{array}{r}\text { Table } 2 . \\
\text { Prominent I4.0 } \\
\text { technologies }\end{array}$ \\
\hline
\end{tabular}

(Liu and $\mathrm{Xu}$, 2016). Some firms have already empowered customers to work as innovators by providing technical support while customers do all the creative work (Cui and $\mathrm{Wu}, 2016$ ).

NPD is a function of joining customers' needs and technology (Dougherty, 1992). Product design and manufacturing are noetic tasks with challenges like customised demand, time pressure and high quality at low costs; better designing techniques and modern technologies have helped the cause (Giret et al., 2016). Additionally, humans are surrounded by a world of non-human resources, and their mutual interaction is inevitable (Bowden, 2015). Therefore, enhanced digital interaction between humans and technologies generates more creational opportunities for customisation. Despite all, corporate practices have given attention to I4.0, but the theoretical contribution is falling behind (Arnold et al., 2016).

\subsection{Customer participation in new product development}

The extant literature has interchangeably used many terms for customer participation, but the three most commonly used are co-production, co-creation and customer participation (Dong and Sivakumar, 2017). We use CP because it is inclusive and more frequently used in the literature (Dong and Sivakumar, 2017). Dong (2015, p. 498) perceives CP as "the act of engaging customers in the design and production of products and services." Innovation, which is also recognised as "new product development" (Dong and Sivakumar, 2017), denotes the conception and development of ideas that bring incremental improvement and/or radical newness to currents offerings of firms (Berry et al., 2006).

Understanding the factors contributing to the new product's success is a vital managerial concern (Mu et al., 2017). One way to lower the risk of product failure is to reduce uncertainty by allowing CP in product innovation (Sawhney et al., 2005) and improving the product-market fit (Poetz and Schreier, 2012). From receiving customers' feedback through interviews and surveys to collect information for the internal research and development (R\&D) departments (Cui and $\mathrm{Wu}, 2017$ ) to the availability of self-service technologies for customers (Meuter et al., 2005) (e.g. check-in transaction at a kiosk, self-service checkout at grocery stores), "the logic of these exhortations have relied almost exclusively on an economic rationale" (Bendapudi and Leone, 
EJIM

25,6

642

2003) of saving costs by substituting customers for employees. However, the NPD is a multifaceted phenomenon reaching beyond the assumed benefits highlighted in the literature (Morgan et al., 2018). It can be challenging for firms to blend the input from the external approach of CP with their internal R\&D programme (Bstieler et al., 2018). Additionally, the existing results of $\mathrm{CP}$ in NPD offer varying findings. Some studies indicate a positive impact of CP in NPD (Carbonell et al., 2009; Mahr et al., 2014), while others found an insignificant or even negative effect (Gruner and Homburg, 2000; Menguc et al., 2014). These inconsistencies in results indicate the presence of contingencies under which $\mathrm{CP}$ can be more or less beneficial.

Firms' inclination towards CP in NPD has three reasons (Rossmann et al., 2016). First, the Internet has facilitated the creation of new channels of customer-firm interaction. Second, customers have increased connectivity and access to information. Third, modern technologies like 3D printing and Web 2.0 have enhanced firms' and customers' ability to co-create with ease due to enhanced connectivity, flexibility and collaboration (Rossmann et al., 2016; Bacile et al., 2014). Cui and Wu (2017, p. 66) argue that "the limited influence of customers in CIS [customer involvement as an information source] does not provide as many opportunities as in CIC [customer involvement as co-developers] to ensure that their creative inputs are understood and utilised in NPD." With I4.0 technologies, customers have become an integral part of the innovation process and can engage themselves in the product development process by using operant resources like knowledge, physical and mental skills, and technology (Vargo and Lusch, 2004, 2017). Now, companies use CP as a source of competitive advantage (Vargo and Lusch, 2016).

\subsection{Hypotheses development}

Chang and Taylor (2016) proposed three NPD phases, namely the ideation stage (idea generation and concept testing), product development stage (development of product design and engineering process) and the launch stage (product launch). Customers should be allowed to participate during these diverse phases (Carbonell et al., 2009). Most of the literature on CP considers the construct as a whole, but some studies have also analysed the individual CP activities within each stage (e.g. Morgan et al., 2018). This article focuses on the product development stage, that is, product design and engineering (production process) (Chang and Taylor, 2016) because technology is most relevant during these activities. The previous literature has also emphasised the importance of engaging customers in the development stage (Coviello and Joseph, 2012).

2.3.1 Customer participation in product design. Product design is a source of competitiveness for firms (Gemser and Leenders, 2001; Noble and Kumar, 2010). By codesigning, customers contribute to the design of the product or service (Kohtamäki and Rajala, 2016). "Technology is as much an operant resource as are human beings" (Ramaswamy and Ozcan, 2018b, p. 203). I4.0 technologies provide firms with more liberty of producing customised products and create new channels of customer interaction, and such engagement is reflected by CP in product design and engineering (Müller et al., 2018). Courtesy of technologies like AM and 3D printing, customers can design and create 3Dprinted products in such industries where customer involvement was previously restricted due to the difficulty of acquiring required tools (Bstieler et al., 2018). With customer involvement, a graphical product configuration is generated, and the personalised prototype is developed with the help of AM and 3D printers, and the computer aided design (CAD) model helps in optimising the geometric parameters of consequent 3D printing (Zheng et al., 2018).

The novelty of the idea of I4.0 is not in new technologies but in combining them in new ways (Drath and Horch, 2014). These technologies operate together in a digitally connected environment and create an interactive manufacturing platform (Ramaswamy and Ozcan, 2018b). For example, 3D printing is a vital component of AM and an example of cyberphysical systems (Li, 2018). AM, 3D printing, augmented reality (AR) and virtual reality (VR), 
integrated with cyber-physical system and IoT, enable the development of prototypes in realtime (Kolarevic, 2004). Customer experience and expectations regarding co-design can be recorded with VR and AR (Zheng et al., 2018). Firms also use a massive volume of data gathered from customers' participation to better understand the customers' choice and pattern of shifting from existing products to new customised demands. The investment in new I4.0 technologies helps manufacture personalised products at lower costs and create a competitive advantage over mass-producing firms (Müller et al., 2018). The implication of I4.0 technologies provide flexibility in production and enable firms to produce individualised products (Bauer and Schlund, 2014; Emmrich et al., 2015).

We claim that if a company adopts one or fewer technologies that can only develop a digital design or prototype of a product, it will be relatively less inclined towards allowing CP in design. Whereas, a company with a higher number of technologies ranging from digital design to the development of finished products will more likely allow $\mathrm{CP}$ in design as it is more equipped with providing customers with the customised product. The individual technologies have their specific use, but companies can generate more possibilities of catering to customised demands by engaging customers in the design process when technologies are used in a connected environment. Grounded in this argument, we propose the following:

H1. Among the adopters of I4.0 technologies, the firms which use more I4.0 technologies allow more customer participation in product design development.

2.3.2 Customer participation in the production process. Co-designing products imply changing roles in a firm's production process (Moreau and Herd, 2010). Participating as co-designers and collaborative partners, customers are increasingly integrated into the design and production of products and services (Wischmann et al., 2015). The technologies and principles of I4.0 influence the production process of goods (de Sousa Jabbour et al., 2018). Companies strive to ensure that even producing a single product should be profitable for them. At the same time, the customers want to reach real-time quality data of the production to guarantee that the products will match their desires (Zheng et al., 2018). The comprehensive interaction between actors is represented by increased customer engagement in the product design and engineering process (Müller et al., 2018). I4.0 provides actual production status and connective technologies to address the desire of $\mathrm{CP}$ in the production process while still safeguarding businesses' profitability. For example, technologies like AR, AM, and 3D printers can project, in advance and during the process, how the manufacturing process will unfold, the amount of work done, and the remaining time and work quality.

In the internet-enabled environment, "mixed-reality interfaces" (AR and VR) of the digitalised world encourage $\mathrm{CP}$ by reducing the distance between actual experience and people (Ramaswamy and Ozcan, 2018a). Automated manufacturing with robotics and supervision with $3 \mathrm{D}$ printers, VR and AR safeguards quality, avoids delays and ensures customers' access to live production and quality data (Nee et al., 2012). From mobile devices like smartphones and tablets, the data regarding every critical machine component can be visualised in real-time (Zheng et al., 2018). As AR and VR can envision the production process, a combination of these digitised technologies and real-time manufacturing data creates a significant interaction between machines and users (Zheng et al., 2018).

$\mathrm{CP}$ in the I4.0 context is happening, and companies are ensuring to make the process transparent. IoT connects different components of the production environment. Enabled by virtual visibility, digital technologies like VR and AR allow end-users to foresee machine data projected on the entire section of a machine (Nee et al., 2012). In I4.0, information visibility plays a crucial role in decision-making (Zheng et al., 2018), and it let customers approach the real-time information of the production stage (Müller et al., 2018). Hence, we expect a positive impact of using more I4.0 technologies on $\mathrm{CP}$ in the production process. Therefore, we hypothesise,

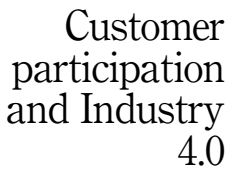

643 
EJIM

25,6
H2. Among the adopters of I4.0 technologies, the firms which use more I4.0 technologies allow more customer participation in the production process.

\section{Research methodology}

\subsection{Data collection}

We used a structured questionnaire and submitted it through computer-assisted web interviewing (CAWI), targeted at chief operating officers or managers in charge of technological and manufacturing processes. Assistance on the phone was provided to the respondents to help them understand the questions as they filled the questionnaire. The research was conducted on a population of 8,022 firms from the AIDA database, which contains comprehensive information on Italian companies (Agostini and Filippini, 2019). The firms belong to made in Italy industries of home furnishing, mechanics, fashion and electronics. The firms' geographical location was Northern Italy (Piedmont, Lombardy, Veneto, Trentino-Alto Adige, Friuli Venezia Giulia, Emilia-Romagna), and they were selected due to their significance in international competitiveness and relevance for Italian gross domestic product (GDP).

At the end of 2016, the Ministry of Economic Development in Italy, the second-largest manufacturing country in Europe, launched an incentivised plan called "National Plan Industry 4.0" encouraging companies to invest in modern technologies. This plan witnessed the implementation of I4.0 by $8.4 \%$ of Italian companies and an $11 \%$ increase in investments in machinery and equipment (MISE, 2018). Therefore, it is appropriate and timely to analyse the impact of I4.0 technologies to explore and guide companies about these technologies' potential. Based on the literature explored, the questionnaire was directed at collecting data on six technologies, namely (1) 3D printers, (2) AM, (3) IoT, (4) robotics, (5) big data and (6) AR. 1,229 firms were interviewed, and the final sample for analysis was $123(10 \%$ of the interviewed firms). The sample size is comparable with existing empirical studies in the I4.0 context (e.g. $n=133$ in Schmidt et al., 2015).

\subsection{Measures}

There are two dependent variables in this study, that is, $\mathrm{CP}$ in product design and $\mathrm{CP}$ in the production process. We consider customer participation as an ordinal variable (Dong and Sivakumar, 2017) and use a five-point Likert scale to measure individual activities of the product development stage, that is, $\mathrm{CP}$ in design and $\mathrm{CP}$ in production. On a five-point Likert scale, 1 represents "not at all" and 5 "very much". The primary independent variable of interest is "I4.0 technologies" and is described as a sum of various technologies (Hermann et al., 2016). It measures the firm's count of adopted technologies, that is, 1 represents a firm using one technology up to a maximum of 6 . Table 3 provides the detail of the measures used for variables and their brief description.

We control for the size of the firms by taking the natural log of the number of employees (Belderbos et al., 2004) because it is challenging for larger firms to involve customers in their product development process as they tend to have a relatively stable and settled system (Schaarschmidt and Kilian, 2014). In contrast, smaller firms are more open and motivated to adopt new techniques and incorporate external output. We also control firms' internal R\&D investments because firms can learn about customer preferences through R\&D and develop new products. R\&D investment is measured by dividing R\&D by sales (Cuervo-Cazurra and Un, 2007). The targeted customers of companies are also controlled for, that is, business to business (B2B) or business to customer (B2C). A dummy variable is included in the analysis to indicate a $\mathrm{B} 2 \mathrm{C}$ context.

The controls for industry type, existing competitive advantages of the firms and location are also included. Although all the firms belong to the North Italian region, the available facilities and infrastructure for a firm in one geographical location (e.g. high-speed Internet) 


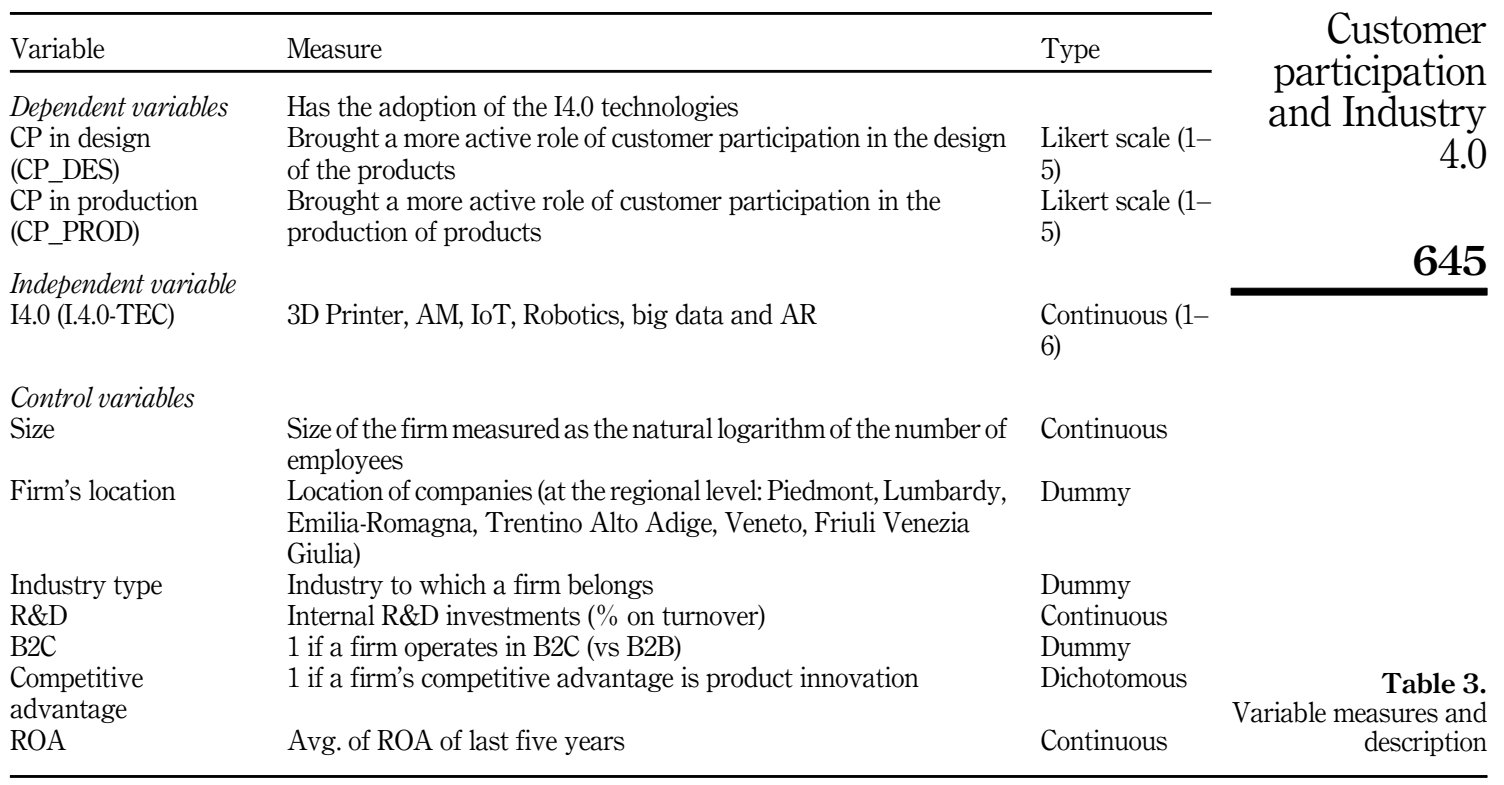

could favour the use of one technology over the other. Hence, the site of the firms was also included as a control variable. The cost-oriented firms adopt I4.0 technologies to increase production efficiency, while the firms which are competitive in product flexibility and innovation are more likely to engage customers in the NPD. Hence, the existing competitive advantage of firms was also controlled. Adopting I4.0 technologies and their integration with the current system require some necessary infrastructure and can be costly. For this reason, firms' financial conditions were also controlled by taking the average return on assets (ROA) of the last five years. Table 4 presents the descriptive statistics and correlations of the study.

\section{Empirical analysis and results}

\subsection{Results}

OLS regression was used to test the proposed relationships of this study: the impact of I4.0 technologies on $\mathrm{CP}$ in product design and production process. The results are reported in Table 5.

\begin{tabular}{|c|c|c|c|c|c|c|c|c|c|c|}
\hline & & Mean & Std. dev & 1 & 2 & 3 & 4 & 5 & 6 & 7 \\
\hline & CP_DES & 2.64 & 1.24 & 1 & & & & & & \\
\hline & CP PROD & 2.11 & 1.10 & $0.60^{* * *}$ & 1 & & & & & \\
\hline & I.4.0_TEC & 2.43 & 1.39 & $0.30^{* *}$ & $0.20^{*}$ & 1 & & & & \\
\hline 4 & SIZE & 3.34 & 1.09 & -0.05 & 0.04 & $0.34^{* * *}$ & 1 & & & \\
\hline & R\&D & 0.001 & 0.01 & 0.14 & 0.03 & -0.08 & -0.36 & 1 & & \\
\hline & B2C & 0.37 & 0.49 & -0.16 & -0.11 & -0.05 & 0.01 & 0.001 & 1 & \\
\hline & ROA & 10,161 & 30,029 & -0.05 & -0.07 & -0.04 & 0.06 & -0.10 & -0.04 & \\
\hline
\end{tabular}

Note(s): **Correlation is significant at the 0.01 level

*Correlation is significant at the 0.05 level

Dummies for industry type, location and competitive advantage are not reported

Table 4.

Descriptive statistics and correlations 


\section{EJIM \\ 25,6}

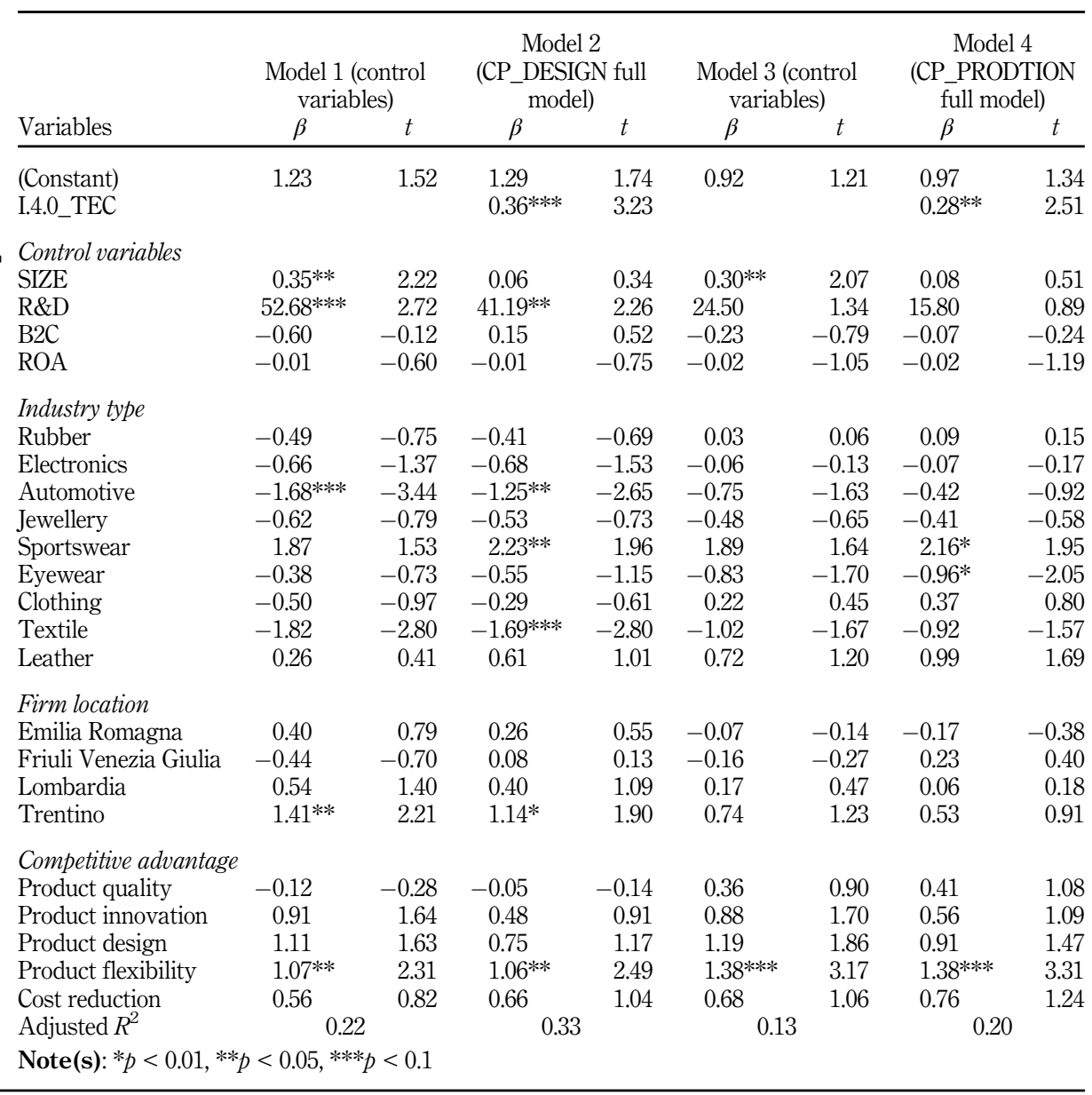

Table 5.

646

Results of the analysis

Model 1 and model 3 are control variables only, while model 2 and model 4 are the full models with the primary variable of interest, that is, I4.0 technologies (I.4.0_TEC). H1 predicted a positive impact of using more I4.0 technologies on CP in product design. Results supported this hypothesis at $p<0.01(0.36)$ and adjusted $R^{2}$ of 0.33 . Model 1 and model 2 show some interesting results. The size of the firm is significant for $\mathrm{CP}$ in product design in model 1 but becomes insignificant in the full model when the I.4.0_TEC variable is included. R\&D is significant in both models 1 and 2, indicating that firms' internal research and information also play an essential role in identifying customers' demands. This result is fascinating as Table 4 does not show any correlation between $\mathrm{R} \& \mathrm{D}$ and $\mathrm{CP}$ either in product design or production process. Model 4 analysed the hypothesised positive impact of using more I4.0 technologies on $\mathrm{CP}$ in the production process. We found empirical support for this hypothesis as well at $p<0.05(0.28)$. The adjusted $R^{2}$ of model $4(0.20)$ is considerably higher than that of model 3 which consists of control variables only. The results of model 3 and model 4 are pretty similar.

Apart from the primary independent variable of interest, that is, I4.0 technologies, there are other valuable insights. Like model 1 and model 2, the firm size is significant in model 3 but becomes insignificant in model 4 when the I4.0 technologies variable is included. 
A plausible explanation of this reversion could be that traditionally, it is more difficult for larger firms to incorporate the ideas and knowledge from external sources into their product development processes. The larger firms tend to rely on their professional product developers and internal research system. With I4.0 technologies, the flow of information and command and control becomes more flexible and decentralised, and it becomes easier for firms to incorporate customers' inputs in the product design and production process, and the firm's size becomes irrelevant thereof. Firms that are competitive in product flexibility are more likely to engage customers in NPD than those competitive in product quality, design and innovation, and low production cost. Industry-specific effects are significant and positive for sportswear in product design and production process, whereas adverse for the automotive and textile sectors in product design and eyewear in the production process.

\subsection{Additional analysis}

Many authors label a specific technology as I4.0. Some scholars considered IoT as I4.0 (Porter and Heppelmann, 2014; Gilchrist, 2016); others labelled 3D printing as a new industrial revolution (Berman, 2012). Similarly, numerous articles explored the impact and usefulness of individual technologies like AM (Ford and Despeisse, 2016), AR (Yew et al., 2016) and big data (Li et al., 2015) in the NPD. To strengthen our study's findings, we conducted additional analysis to investigate the impact of individual technologies on $\mathrm{CP}$ in the design and production process. One argument in performing the principal analysis of this study was that the individual technologies have their specific use, while their connected use could open a broader and new set of opportunities for product development. To validate our claim, we explored the firms' perspective on the use of individual technologies. For this, we replaced the variable "I4.0 technologies (I.4.0_TEC)" with individual technologies, 3D printer, AM, IoT, robotics, big data, and AR, in two models while keeping all other variables in the analysis. We tested both the models to analyse the impact of individual technologies on $\mathrm{CP}$ in the product design and production process.

The additional analysis provided some unexpected and stimulating results reported in Table 6. The use of 3D printers had no significant impact on $\mathrm{CP}$ either in product design or the production process. It is surprising because 3D printers are generally believed to be ideal for product customisation and production of individual products. However, AM, which also works on similar principles as $3 \mathrm{D}$ printers, positively impacted $\mathrm{CP}$ in product design $(=0.77, p<0.05)$. The use of AR showed a significant positive impact in both models, that is, $\mathrm{CP}$ in the design and production process $(=1.02, p<0.05 ;=0.81, p<0.05)$. This could be because AR helps firms incorporate customers' input in a virtual environment and see the expected product before committing the resources into actual production. Robotics and $\mathrm{AM}$ are insignificant for $\mathrm{CP}$ in the production process. Big data shows a minor negative impact on $\mathrm{CP}$ in production $(=-0.47$,

\begin{tabular}{|c|c|c|c|c|}
\hline \multirow[b]{2}{*}{ Variables } & \multicolumn{2}{|c|}{$\begin{array}{l}\text { Model } 1 \\
\text { CP_DES }\end{array}$} & \multicolumn{2}{|c|}{$\begin{array}{c}\text { Model } 2 \\
\text { CP_PROD }\end{array}$} \\
\hline & $\beta$ & $t$ & $\beta$ & $t$ \\
\hline (Constant) & 0.52 & 0.68 & 0.81 & 1.09 \\
\hline $3 \mathrm{D}$ printer & -0.29 & -0.76 & 0.45 & 1.24 \\
\hline $\mathrm{AM}$ & $0.77^{* *}$ & 2.20 & 0.16 & 0.49 \\
\hline $\mathrm{AR}$ & $1.02^{* *}$ & 2.67 & $0.81 * *$ & 2.18 \\
\hline Robotics & $0.59 * *$ & 2.09 & 0.28 & 1.00 \\
\hline Big data & -0.39 & -1.42 & $-0.47^{*}$ & -1.76 \\
\hline IoT & -0.11 & -0.21 & 0.32 & 0.64 \\
\hline Adjusted $R^{2}$ & & & & \\
\hline
\end{tabular}

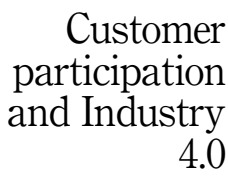

647

Note(s): $* p<0.01, * * p<0.05$ 
EJIM

25,6

648

$p<0.1)$ and a negative but insignificant impact on $\mathrm{CP}$ in product design. A probable explanation of this negative impact could be that with the help of big data, firms might find themselves capable of producing customised products on their own and hence, oppose CP. An alternative perspective might be that in the presence of big data and the connected environment, courtesy of IoT, the systems become more transparent, which may expose the inefficiencies of firms, which, in return, discourage them from allowing customer participation.

Although the results of both analyses make a valuable and unique contribution and provide significant insights into the potentials of I4.0 technologies in product customisation, we did not collect the data on the level of investments in these technologies. Additionally, the optimal combination of these technologies to get the optimal results is beyond the scope of this study. So the presence of a bias cannot be completely ruled out. Therefore, a cautious interpretation of the results and further research is required before generalising these findings.

\section{Discussion}

Our analysis supports a positive impact of higher adoption of I4.0 technologies on CP in the product development stage, that is, $\mathrm{CP}$ in product design and the production process. A more substantial and significant impact of using more I4.0 technologies on $\mathrm{CP}$ was found in product design than in the production process. This could be because, during the design development of a new product, the customer inputs are mostly transformed into digital and computer-aided designs. The firms have not yet committed the resources in the production process, and the desired changes in computer-aided designs are relatively more comfortable. Once the production process starts, the incorporation of customer inputs is relatively tricky as different elements are connectedly working in the production process, and changes in one would lead to modifications in the whole process. This causes a relatively less significant impact of I4.0 technologies on $\mathrm{CP}$ in the production process than in product design.

This study contributes to the theoretical advancement in the literature on I4.0 technologies and $\mathrm{CP}$ in NPD and provides relevant managerial implications. First, we empirically documented firms' perspective of using I4.0 technologies to produce customised products, a claim infrequently analysed empirically. The baseline of the idea of I4.0 technologies is about revolutionising the production in an age of digitalised interactions where it is inadequate to grasp new opportunities through the traditional notion of offering a fixed set of features in products and services (Ramaswamy and Ozcan, 2018a). Others argue that individually, the technologies are in use for quite a while now, and I4.0 puts forward the idea to use them in a connected environment at a larger scale (Santos et al., 2017). According to our empirical analysis, it emerges that different I4.0 technologies may improve the $\mathrm{CP}$, supporting the theoretical concept of the relevance of customers' knowledge for innovation. More specifically, our study in the I4.0 framework suggests that only single technologies do not matter; instead, firms may invest in multiple technologies to exploit the full potential of $\mathrm{CP}$ for product design and production. From this perspective, managers aiming to benefit from $\mathrm{CP}$ should enlarge the scope of their I4.0 investments and consider the different roles concerning the design and production stages of the new product development process.

Secondly, our study provides empirical evidence on the potentialities of I4.0 investments for CP by enriching the past literature focused on ICT and the development of virtual customer environments for NPD. The fourth industrial revolution advances CP by allowing customers to enter into the design and production processes, specifically rooted in different I4.0 technologies. In this regard, the I4.0 framework confirms to be particularly relevant for supporting customisation (Culot et al., 2020) based on the active role of customers. From a managerial point of view, this result is relevant for adopters since it highlights that firms may benefit from an improved offering developed with the help of customers, thus reducing the problems of misalignment between the firm and the market. By combining different I4.0 
technologies, the possibility of understanding market needs and customers' dynamics to delineate appropriate market strategies and value creation becomes more efficient.

Third, we got the support for H2, which predicted a positive impact of I4.0 technologies on $\mathrm{CP}$ in the production process. The existing literature argues that firms are traditionally reluctant to encounter customers in their production process. Firms have concerns regarding the spillover of know-how and procedures, especially the deep-routed syndrome of "not invented here" (Katz and Allen, 1984). Sometimes customers are not interested to know how the product is produced or they may also lack awareness regarding the production process (Lukas et al., 2013). Our study reinforces the theoretical approach that identifies customers' "maker" nature, contributing to the literature highlighting CP beyond idea generation to include the manufacturing dimension of customers' inputs. This result is also relevant from a managerial point of view since it identifies a more extended, interconnected manufacturing process characterising the fourth industrial revolution where (active) customers are part of the organisation when production processes are concerned. This opens new issues for managers regarding the definition of incentives for $\mathrm{CP}$ and new logics in the organisation of manufacturing activities to effectively involve external actors in the firm processes.

The type of industry a firm is operating in, the physical location of facilities and the existing competitiveness had a varying approach towards allowing CP in NPD. The sportswear firms were more prone to $\mathrm{CP}$ than others. Moreover, firms with a competitive advantage in product flexibility granted more $\mathrm{CP}$ in two models. It highlights how firms should adjust their processes - product development and manufacturing processes concerning customisation to exploit the advantages of I4.0, allowing better customer connectivity and intimacy (Iansiti and Lakhani, 2014) with customers for improved NPD.

\section{Conclusions}

The role of $\mathrm{CP}$ in innovation dynamics and NPD has been a focus of several studies interested in exploring the structure and consequences of $\mathrm{CP}$ and how specific technologies may support such dynamics. Our study concentrated on I4.0 technologies and provided additional comprehension of this phenomenon by disentangling the role of $\mathrm{CP}$ in the product design and production processes. Moving away from the technical aspects and highlighting the strategic adoption of I4.0 technologies, this paper explored the impact of using more I4.0 technologies on $\mathrm{CP}$ in the NPD process of a firm. The results supported the proposed hypotheses of this study and established that when technologies are used in a connected mode, companies are better able to involve customers in the product design and production process. This positive impact is more substantial in product design than in the production process. As technologies, physical and virtual components are increasingly getting digitised and connected, their implication in value creation is also increasing. Therefore, while on the one hand, individual technologies have their specific characteristics and role in terms of product customisation, their combined use better poised firms in meeting the customers' demands by providing customised products. In the fourth industrial revolution scenario, attention on CP is essential to reinforce customers' relevance in shaping firms' offering. Finally, firms should adopt an integrated approach to invest in I4.0 technologies because, besides the advantages of specific technologies and their benefits for firms, the potentialities of I4.0 reside in the connected use of technologies.

This study has some limitations as well, which provide a way for future research. First, this study uses the data of the firms which are the adopters of I4.0 technologies. Although this study fills an essential gap in postulating firms' perspective of using these modern technologies, a comparative study between adopting and non-adopting firms regarding their behaviour towards allowing more CP in NPD will be a vital follow-up study. We documented that the I4.0 technologies work better in a connected environment, and higher the number of technologies a firm uses, the more customer participation is ensured. A modest 
EJIM

25,6

understanding of this argument can be misleading as the paper does not discuss the most effective combinations of technologies or any specific technology which plays a central role in the connected environment. Focussing on CP in NPD did not cater to CP's impact outside the NPD process. Although we narrowed down CP to the product development stage, we did not differentiate between the specific nature of $\mathrm{CP}$, which is a limitation. We used simple OLS for the analysis. Future studies can use other sophisticated techniques like a longitudinal study to report the changes over time.

\section{References}

Agostini, L. and Filippini, R. (2019), "Organizational and managerial challenges in the path toward Industry 4.0", European Journal of Innovation Management, Vol. 22 No. 3, pp. 406-421.

Al-Fuqaha, A., Guizani, M., Mohammadi, M., Aledhari, M. and Ayyash, M. (2015), "Internet of things: a survey on enabling technologies, protocols, and applications", IEEE Communications Surveys and Tutorials, Vol. 17 No. 4, pp. 2347-2376.

Arnold, C., Kiel, D. and Voigt, K.I. (2016), "How the industrial internet of things changes business models in different manufacturing industries", International Journal of Innovation Management, Vol. 20 No. 8, p. 1640015.

Babiceanu, R.F. and Seker, R. (2016), "Big data and virtualization for manufacturing cyber-physical systems: a survey of the current status and future outlook", Computers in Industry, Vol. 81, pp. 128-137.

Bacile, T.J., Ye, C. and Swilley, E. (2014), "From firm-controlled to consumer-contributed: consumer coproduction of personal media marketing communication", Journal of Interactive Marketing, Elsevier B.V, Vol. 28 No. 2, pp. 117-133.

Bauernhansl, T., Hompel, M.T. and Vogel-Heuser, B. (2014), Industrie 4.0 in produktion, automatisierung und logistik, Springer Vieweg, Wiesbaden, p. 639.

Bauer, W. and Schlund, S. (2014), Volkswirtschaftliches potenzial für Deutschland, BITKOM, Fraunhofer IAO, Berlin, Stuttgart.

Belderbos, R., Carree, M. and Lokshin, B. (2004), "Cooperative R\&D and firm performance”, Research Policy, Vol. 33 No. 10, pp. 1477-1492.

Bendapudi, N. and Leone, R.P. (2003), "Psychological implications of customer participation in coproduction", Journal of Marketing, Vol. 67, pp. 14-28.

Berman, B. (2012), “3-D printing: the new industrial revolution”, Business Horizons, Vol. 55, pp. 155-162.

Berry, L.L., Shankar, V., Parish, J.T., Cadwallader, S. and Dotzel, T. (2006), "Creating new markets through service innovation", MIT Sloan Management Review, Vol. 47 No. 2, p. 56.

Bidet-Mayer, T. and Ciet, N. (2016), L'industrie du futur: une compétition mondiale, La Fabrique de l'Industrie.

Bogers, M., Hadar, R. and Bilberg, A. (2016), "Additive manufacturing for consumer-centric business models: implications for supply chains in consumer goods manufacturing", Technological Forecasting and Social Change, Vol. 102, pp. 225-239.

Bowden, S. (2015), "Human and nonhuman agency in Deleuze", in Roffe, J. and Stark, H. (Eds), Deleuze and the Non/Human, Palgrave Macmillan, London, pp. 60-80.

Bressanelli, G., Adrodegari, F., Perona, M. and Saccani, N. (2018), "Exploring how usage-focused business models enable circular economy through digital technologies", Sustainability, Vol. 10 No. 3, p. 639 .

Bstieler, L., Gruen, T., Akdeniz, B., Brick, D., Du, S., Guo, L., Khanlari, M., McIllroy, J., O'Hern, M. and Yalcinkaya, G. (2018), "Emerging research themes in innovation and new product development: insights from the 2017 PDMA-UNH Doctoral Consortium", Journal of Product Innovation Management, Vol. 35 No. 3, pp. 300-307. 
Buer, S.V., Strandhagen, J.O. and Chan, F.T.S. (2018), "The link between industry 4.0 and lean manufacturing: mapping current research and establishing a research agenda", International Journal of Production Research, Vol. 56 No. 8, pp. 2924-2940.

Carbonell, P., Rodríguez-Escudero, A.I. and Pujari, D. (2009), "Customer involvement in new service development: an examination of antecedents and outcomes", Journal of Product Innovation Management, Vol. 26 No. 5, pp. 536-550.

Chan, S.L., Lu, Y. and Wang, Y. (2018), "Data-driven cost estimation for additive manufacturing in cybermanufacturing”, Journal of Manufacturing Systems, Vol. 46, pp. 115-126.

Customer participation and Industry

Chang, W. and Taylor, S.A. (2016), "The effectiveness of customer participation in new product development: a meta-analysis", Journal of Marketing, Vol. 80 No. 1, pp. 47-64.

Chiarello, F., Trivelli, L., Bonaccorsi, A. and Fantoni, G. (2018), "Extracting and mapping industry 4.0 technologies using wikipedia", Computers in Industry, Vol. 100, pp. 244-257.

Cimini, C., Boffelli, A., Lagorio, A., Kalchschmidt, M. and Pinto, R. (2020), "How do industry 4.0 technologies influence organisational change? An empirical analysis of Italian SMEs", Journal of Manufacturing Technology Management, Vol. 32 No. 3, pp. 695-721.

Coviello, N.E. and Joseph, R.M. (2012), "Creating major innovations with customers: insights from small and young technology firms", Journal of Marketing, Vol. 76 No. 6, pp. 87-104.

Cuervo-Cazurra, A. and Un, C.A. (2007), "Regional economic integration and R\&D investment", Research Policy, Vol. 36 No. 2, pp. 227-246.

Cui, A.S. and Wu, F. (2016), "Utilizing customer knowledge in innovation: antecedents and impact of customer involvement on new product performance", Journal of the Academy of Marketing Science, Vol. 44 No. 4, pp. 516-538.

Cui, A.S. and Wu, F. (2017), "The impact of customer involvement on new product development: contingent and substitutive effects", Journal of Product Innovation Management, Vol. 34 No. 1, pp. 60-80.

Cui, A.S. and Wu, F. (2018), "Customer Involvement in innovation: a review of literature and future research directions", Innovation and Strategy, pp. 63-98.

Culot, G., Nassimbeni, G., Orzes, G. and Sartor, M. (2020), "Behind the definition of Industry 4.0: analysis and open questions", International Journal of Production Economics, Vol. 226, p. 107617.

de Sousa Jabbour, A.B.L., Jabbour, C.J.C., Foropon, C. and Godinho Filho, M. (2018), "When titans meet - can industry 4.0 revolutionise the environmentally-sustainable manufacturing wave? The role of critical success factors", Technological Forecasting and Social Change, Vol. 132, pp. 18-25.

Dong, B. (2015), "How a customer participates matters: 'I am producing' versus 'I am designing”, Journal of Services Marketing, Vol. 29 Nos 6-7, pp. 498-510.

Dong, B. and Sivakumar, K. (2017), "Customer participation in services: domain, scope, and boundaries", Journal of the Academy of Marketing Science, Vol. 45 No. 6, pp. 944-965.

Doshi, A., Smith, R.T., Thomas, B.H. and Bouras, C. (2017), "Use of projector based augmented reality to improve manual spot-welding precision and accuracy for automotive manufacturing", The International Journal of Advanced Manufacturing Technology, Vol. 89 Nos 5-8, pp. 1279-1293.

Dougherty, D. (1992), "A practice-centered model of organizational renewal through product innovation", Strategic Management Journal, Vol. 13, pp. 77-92.

Drath, R. and Horch, A. (2014), "Industrie 4.0: hit or hype?", IEEE Industrial Electronics Magazine, Vol. 8 No. 2, pp. 56-58.

Emmrich, V., Döbele, M., Bauernhansl, T., Paulus-Rohmer, D., Schatz, A. and Weskamp, M. (2015), Geschäftsmodell-Innovation durch Industrie 4.0: Chancen und Risiken für den Maschinen- und Anlagenbau, Dr. Wieselhuber and Partner, Fraunhofer IPA, München Stuttgart.

Esmaeilian, B., Behdad, S. and Wang, B. (2016), "The evolution and future of manufacturing: a review", Journal of Manufacturing Systems, Vol. 39, pp. 79-100. 
EJIM

25,6
Fang, E.E. (2008), "Customer participation and the trade-off between new product innovativeness and speed to market", Journal of Marketing, Vol. 72 No. 4, pp. 90-104.

Ford, S. and Despeisse, M. (2016), "Additive manufacturing and sustainability: an exploratory study of the advantages and challenges", Journal of Cleaner Production, Vol. 137, pp. 1573-1587.

Gemser, G. and Leenders, M.A.A.M. (2001), "How integrating industrial design in the product development process impacts on company performance", Journal of Product Innovation Management, Vol. 18 No. 1, pp. 28-38.

Ghobakhloo, M. (2018), “The future of manufacturing industry: a strategic roadmap toward Industry 4.0", Journal of Manufacturing Technology Management, Vol. 29 No. 6, pp. 910-936.

Gilchrist, A. (2016), Industry 4.0: The Industrial Internet of Things, Apress.

Giret, A., Garcia, E. and Botti, V. (2016), "An engineering framework for service-oriented intelligent manufacturing systems”, Computers in Industry, Vol. 81, pp. 116-127.

Gress, D.R. and Kalafsky, R.V. (2015), "Geographies of production in 3D: theoretical and research implications stemming from additive manufacturing", Geoforum, Vol. 60, No. 2015, pp. 43-52.

Griffin, A. and Hauser, J.R. (1993), "The voice of the customer", Marketing Science, Vol. 12 No. 1, pp. 1-27.

Gruner, K.E. and Homburg, C. (2000), "Does customer interaction enhance new product success?", Journal of Business Research, Vol. 49 No. 1, pp. 1-14.

Hermann, M., Pentek, T. and Otto, B. (2016), "Design principles for Industrie 4.0 scenarios”, IEEE 49th Hawaii International Conference on System Sciences, pp. 3928-3937.

Hibbert, S.A., Piacentini, M.G. and Hogg, M.K. (2012), "Service recovery following dysfunctional consumer participation", Journal of Consumer Behaviour, Vol. 11, pp. 329-338.

Holmström, J., Holweg, M., Khajavi, S.H. and Partanen, J. (2016), “The direct digital manufacturing (r) evolution: definition of a research agenda", Operations Management Research, Vol. 9 No. 1, pp. 1-10.

Huang, S.H., Liu, P., Mokasdar, A. and Hou, L. (2013), “Additive manufacturing and its societal impact: a literature review", The International Journal of Advanced Manufacturing Technology, Vol. 67 No. 5, pp. 1191-1203.

Iansiti, M. and Lakhani, K.R. (2014), "Digital ubiquity: how connections, sensors, and data are revolutionizing business", Harvard Business Review, Vol. 92 No. 11, p. 19.

IFR (2017), "Executive summary world robotics 2017 industrial robots", available at: https:/ifr.org/ downloads/press/Executive_Summary_WR_2017_Industrial_Robots.pdf.

Ivanov, D., Dolgui, A., Sokolov, B., Werner, F. and Ivanova, M. (2016), "A dynamic model and an algorithm for short-term supply chain scheduling in the smart factory industry 4.0", International Journal of Production Research, Vol. 54 No. 2, pp. 386-402.

Jeschke, S., Brecher, C., Meisen, T., Özdemir, D. and Eschert, T. (2017), "Industrial internet of things and cyber manufacturing systems", in Industrial Internet of Things, Springer, Cham, pp. 3-19.

Kagermann, H., Wahlster, W. and Helbig, J. (2013), Securing the Future of German Manufacturing Industry: Recommendations for Implementing the Strategic Initiative INDUSTRIE 4.0, Final Report of the Industrie, Vol. 4.

Kang, H.S., Lee, J.Y., Choi, S., Kim, H., Park, J.H., Son, J.Y., Kim, B.H. and Do Noh, S. (2016), "Smart manufacturing: past research, present findings, and future directions", International Journal of Precision Engineering and Manufacturing - Green Technology, Vol. 3 No. 1, pp. 111-128.

Katz, R. and Allen, T.J. (1984), "Organizational issues in the introduction of new technologies", The Management of Productivity and Technology in Manufacturing, pp. 275-300.

Koh, L., Orzes, G. and Jia, F. (2019), "The fourth industrial revolution (Industry 4.0): technologies disruption on operations and supply chain management", International Journal of Operations and Production Management, Vol. 39 No. 6, pp. 817-828. 
Kohtamäki, M. and Rajala, R. (2016), "Theory and practice of value co-creation in B2B systems", Industrial Marketing Management, Vol. 56, pp. 4-13.

Kolarevic, B. (Ed.) (2004), Architecture in the Digital Age: Design and Manufacturing, Taylor \& Francis.

Kolberg, D., Knobloch, J. and Zühlke, D. (2017), "Towards a lean automation interface for workstations", International Journal of Production Research, Vol. 55 No. 10, pp. 2845-2856.

Kotha, S. (1996), "From mass production to mass customization: the case of the national industrial bicycle company of Japan", European Management Journal, Vol. 14 No. 5, pp. 442-450.

Lasi, H., Fettke, P., Kemper, H.G., Feld, T. and Hoffmann, M. (2014), "Industry 4.0", Business and Information Systems Engineering, Vol. 6 No. 4, pp. 239-242.

LaValle, S., Lesser, E., Shockley, R., Hopkins, M.S. and Kruschwitz, N. (2011), "Big data, analytics and the path from insights to value", MIT Sloan Management Review, Vol. 52 No. 2, pp. 21-32.

Li, L. (2018), “China's manufacturing locus in 2025: with a comparison of 'Made-in-China 2025' and 'Industry 4.0”, Technological Forecasting and Social Change, Vol. 135, pp. 66-74.

Li, J., Tao, F., Cheng, Y. and Zhao, L. (2015), "Big data in product lifecycle management", International Journal of Advanced Manufacturing Technology, Vol. 81 No. 1, pp. 667-684.

Liao, Y., Deschamps, F., Loures, E.D.F.R. and Ramos, L.F.P. (2017), "Past, present and future of Industry 4.0 - a systematic literature review and research agenda proposal", International Journal of Production Research, Vol. 55 No. 12, pp. 3609-3629.

Lin, D., Lee, C.K., Lau, H. and Yang, Y. (2018), "Strategic response to Industry 4.0: an empirical investigation on the Chinese automotive industry", Industrial Management and Data Systems, Vol. 118 No. 3, pp. 589-605.

Liu, Y. and Xu, X. (2016), "Industry 4.0 and cloud manufacturing: a comparative analysis", Journal of Manufacturing Science and Engineering, Vol. 139 No. 3, p. 034701.

Lukas, B.A., Whitwell, G.J. and Heide, J.B. (2013), "Why do customers get more than they need? How organizational culture shapes product capability decisions", Journal of Marketing, Vol. 77 No. 1, pp. 1-12.

Mahr, D., Lievens, A. and Blazevic, V. (2014), "The value of customer cocreated knowledge during the innovation process", Journal of Product Innovation Management, Vol. 31 No. 3, pp. 599-615.

Maynard, A.D. (2015), "Navigating the fourth industrial revolution", Nature Nanotechnology, Vol. 10 No. 12, pp. 1005-1006.

Menguc, B., Auh, S. and Yannopoulos, P. (2014), "Customer and supplier involvement in design: the moderating role of incremental and radical innovation capability", Journal of Product Innovation Management, Vol. 31 No. 2, pp. 313-328.

Meuter, M.L., Bitner, M.J., Ostrom, A.L. and Brown, S.W. (2005), "Choosing among alternative service delivery modes: an investigation of customer trial of self-service technologies", Journal of Marketing, Vol. 69 No. 2, pp. 61-83.

MISE - Ministero dello sviluppo economico (2018), La diffusione delle imprese 4.0 e le politiche: evidenze 2017.

Moeuf, A., Pellerin, R., Lamouri, S., Tamayo-Giraldo, S. and Barbaray, R. (2017), "The industrial management of SMEs in the era of Industry 4.0", International Journal of Production Research, Vol. 56 No. 3, pp. 1118-1136.

Moreau, C.P. and Herd, K.B. (2010), "To each his own? How comparisons with others influence consumers' evaluations of their self-designed products", Journal of Consumer Research, Vol. 36 No. 5 , pp. 806-819.

Morgan, T., Obal, M. and Anokhin, S. (2018), "Customer participation and new product performance: towards the understanding of the mechanisms and key contingencies", Research Policy, Vol. 47 No. 2, pp. 498-510.

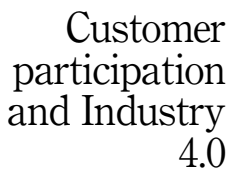

653 
EJIM

25,6

Mu, J., Thomas, E., Peng, G. and Di Benedetto, A. (2017), "Strategic orientation and new product development performance: the role of networking capability and networking ability", Industrial Marketing Management, Vol. 64, pp. 187-201.

Müller, J.M., Buliga, O. and Voigt, K.I. (2018), "Fortune favors the prepared: how SMEs approach business model innovations in Industry 4.0", Technological Forecasting and Social Change, Vol. 132, pp. 2-17.

Nambisan, S. (2002), "Designing virtual customer environments for new product development: toward a theory", Academy of Management Review, Vol. 27 No. 3, pp. 392-413.

Nee, A.Y., Ong, S.K., Chryssolouris, G. and Mourtzis, D. (2012), "Augmented reality applications in design and manufacturing”, CIRP Annals, Vol. 61 No. 2, pp. 657-679.

Noble, C.H. and Kumar, M. (2010), "Exploring the appeal of product design: a grounded, value-based model of key design elements and relationships", Journal of Product Innovation Management, Vol. 27 No. 5, pp. 640-657.

OECD (2017), The Next Production Revolution, the Next Production Revolution, OECD Publishing, Paris.

Poetz, M.K. and Schreier, M. (2012), "The value of crowdsourcing: can users really compete with professionals in generating new product ideas?", Journal of Product Innovation Management, Vol. 29 No. 2, pp. 245-256.

Porter, M.E. and Heppelmann, J.E. (2014), "How smart, connected products are transforming companies", Harvard Business Review, Vol. 92 No. 11, pp. 64-88.

Ramaswamy, V. and Ozcan, K. (2018a), "Offerings as digitalized interactive platforms: a conceptual framework and implications”, Journal of Marketing, Vol. 82, pp. 19-31.

Ramaswamy, V. and Ozcan, K. (2018b), "What is co-creation? An interactional creation framework and its implications for value creation", Journal of Business Research, Vol. 84, pp. 196-205.

Rauch, E., Dallasega, P. and Matt, D.T. (2016), "The way from lean product development (LPD) to smart product development (SPD)”, Procedia CIRP, Vol. 50, pp. 26-31.

Rauch, E., Dallasega, P. and Matt, D.T. (2017), "Critical factors for introducing lean product development to small and medium sized enterprises in Italy", Procedia CIRP, Vol. 60, pp. 362-367.

Rayna, T. and Striukova, L. (2016), "From rapid prototyping to home fabrication: how 3D printing is changing business model innovation", Technological Forecasting and Social Change, Vol. 102, pp. 214-224.

Rossmann, A., Ranjan, K.R. and Sugathan, P. (2016), "Drivers of user engagement in eWoM communication", Journal of Services Marketing, Vol. 30 No. 5, pp. 541-553.

Rüßmann, M., Lorenz, M., Gerbert, P., Waldner, M., Justus, J., Engel, P. and Harnisch, M. (2015), "Industry 4.0: the future of productivity and growth in manufacturing industries", Boston Consulting Group, Vol. 9 No. 1, pp. 54-89.

Santos, C., Mehrsai, A., Barros, A.C., Araújo, M. and Ares, E. (2017), "Towards Industry 4.0: an overview of European strategic roadmaps", Procedia Manufacturing, Vol. 13, pp. 972-979.

Sawhney, M., Verona, G. and Prandelli, E. (2005), "Collaborating to create: the internet as a platform for customer engagement in product innovation", Journal of Interactive Marketing, Vol. 19 No. 4, pp. 4-34.

Schaarschmidt, M. and Kilian, T. (2014), "Impediments to customer integration into the innovation process: a case study in the telecommunications industry", European Management Journal, Vol. 32 No. 2, pp. 350-361.

Schmidt, R., Möhring, M., Härting, R.C., Reichstein, C., Neumaier, P. and Jozinović, P. (2015), "Industry 4.0-potentials for creating smart products: empirical research results", in International Conference on Business Information Systems, Springer, Cham, pp. 16-27. 
Schwab, K. (2016), The Fourth Industrial Revolution: What it Means and How to Respond, World Economic Forum, Geneva.

Sestino, A., Prete, M.I., Piper, L. and Guido, G. (2020), "Internet of Things and Big Data as enablers for business digitalization strategies", Technovation, Vol. 13, p. 102173.

Song, M., Dyer, B. and Thieme, R.J. (2006), "Conflict management and innovation performance: an integrated contingency perspective", Journal of the Academy of Marketing Science, Vol. 34 No. 3, pp. 341-356.

Troye, S.V. and Supphellen, M. (2012), "Consumer participation in coproduction: 'I made it myself' effects on consumers' sensory perceptions and evaluations of outcome and input product", Journal of Marketing, Vol. 76 No. 2, pp. 33-46.

Vargo, S.L. and Lusch, R.F. (2004), "Evolving to a new dominant logic for Marketing", Journal of Marketing, Vol. 68 No. 1, pp. 1-17.

Vargo, S.L. and Lusch, R.F. (2016), "Institutions and axioms: an extension and update of servicedominant logic", Journal of the Academy of Marketing Science, Vol. 44 No. 1, pp. 5-23.

Vargo, S.L. and Lusch, R.F. (2017), "Service-dominant logic 2025”, International Journal of Research in Marketing, Vol. 34 No. 1, pp. 46-67.

von Hippel, E. (1986), "Lead users: a source of novel product concepts", Management Science, Vol. 32 No. 7, pp. 791-805.

Von Hippel, E. (2001), "Perspective: user toolkits for innovation", Journal of Product Innovation Management, Vol. 18 No. 4, pp. 247-257.

Wang, S., Wan, J., Li, D. and Zhang, C. (2016), "Implementing smart factory of Industrie 4.0: an outlook", International Journal of Distributed Sensor Networks, Vol. 12 No. 1, p. 3159805.

Watson, R., Wilson, H.N., Smart, P. and Macdonald, E.K. (2018), "Harnessing difference: a capabilitybased framework for stakeholder engagement in environmental innovation", Journal of Product Innovation Management, Vol. 35 No. 2, pp. 254-279.

Weking, J., Stöcker, M., Kowalkiewicz, M., Böhm, M. and Krcmar, H. (2020), "Leveraging Industry 4.0 a business model pattern framework", International Journal of Production Economics, Vol. 225, 107588.

Wischmann, S., Wangler, L. and Botthof, A. (2015), Industrie 4.0: Volks-und betriebswirtschaftliche Faktoren für den Standort Deutschland, Eine Studie im Rahmen der Begleitforschung zum Technologieprogramm AUTONOMIK für Industrie, p. 4.

Xie, J., Song, X.M. and Stringfellow, A. (1998), "Interfunctional conflict, conflict resolution styles, and new product success: a four-culture comparison”, Management Science, Vol. 44 Nos 12part-2, pp. S192-S206.

Yew, A.W.W., Ong, S.K. and Nee, A.Y.C. (2016), "Towards a griddable distributed manufacturing system with augmented reality interfaces", Robotics and Computer-Integrated Manufacturing, Vol. 39, pp. 43-55.

Zheng, P., Sang, Z., Zhong, R.Y., Liu, Y., Liu, C., Mubarok, K., Yu, S. and Xu, X. (2018), "Smart manufacturing systems for Industry 4.0: conceptual framework, scenarios, and future perspectives", Frontiers of Mechanical Engineering, Vol. 13 No. 2, pp. 137-150.

\section{Corresponding author}

Hafiz Muhammad Naeem can be contacted at: hafizmuhammad.naeem@unipd.it

For instructions on how to order reprints of this article, please visit our website:

www.emeraldgrouppublishing.com/licensing/reprints.htm

Or contact us for further details: permissions@emeraldinsight.com 